\title{
ОЦЕНКА РИСКОВ РАСПРОСТРАНЕНИЯ ГЕНЕТИЧЕСКИ МОДИФИЦИРОВАННОЙ КУКУРУЗЫ С ПЫЛЫЦОЙ ПРИ ВЫРАЩИВАНИИ С НЕТРАНСФОРМИРОВАННЫМИ СОРТАМИ
}

\author{
(обзор)
}

\author{
М.И. ЧУМАКОВ 1 , Ю.С. ГУСЕВ 1 , Н.В. БОГАТЫРЕВА², А.Ю. СОКОЛОВ 2
}

Крупномасштабное промышленное производство генетически модифицированных (ГМ) растений, и в частности кукурузы, началось в 1996 году. К 2016 году площадь, занимаемая ГМкультурами, увеличилась в 100 раз, при этом почти треть этих площадей занимает ГМ-кукуруза, поэтому вопросы ее распространения и перекрестного опыления стали более актуальными в практическом аспекте. В Россия никогда не выращивали ГМ-культуры, хотя уже 10 лет назад в Российской Федерации прошли исследования и были разрешены для использования 15 ГМлиний, в том числе 8 - кукурузы. Федеральным законом от 3 июля 2016 года № 358-Ф3 установлен запрет на коммерческое выращивание ГМ-растений в России, но впервые разрешено выращивать и тестировать ГМ-растения в научных целях. Однако необходимая правовая база для проведения таких исследований не была разработана ни до, ни после вступления в силу Федерального закона № 358-ФЗ. Согласно Конвенции по биоразнообразию (1993), каждая странаучастница должна разработать стратегию и программу по сохранению и использованию своих биоресурсов, принимая во внимание их гарантированное и безопасное воспроизводство. Следовательно, в России имеется существенная необходимость оценки и разработки отсутствующих в настоящее время критериев безопасного совместного выращивания нетрансформированных и ГМ-сортов и линий, обеспечивающего сохранение биоразнообразия, с учетом мирового опыта в экспериментальной оценке возможных экологических и агротехнических рисков при выращивании ГМ-сортов растений, в частности кукурузы. В России такой анализ ранее не проводился. Представляемый обзор восполняет этот пробел. Нами рассмотрены факторы, влияющие на распространение пылыцы кукурузы: ветер (скорость и направление), влажность (дождь), физиология (жизнеспособность), количество пылыцы, характер ландшафта, размеры, форма и ориентация реципиентного поля, синхронность цветения донора и реципиента пылыцы. Ранние исследования потока генов при перекрестном опылении рассмотрены в обобщающих работах (Y. Devos c coавт., 2005; О. Sanvido с соавт., 2008). Однако различия в подходах, аналитических методах и схемах экспериментов препятствуют сравнению результатов и усложняют определение мер по ограничению перекрестного опыления в полевых условиях. В частности, расстояние между ГМи неГМ-кукурузой, рекомендуемое в странах Евросоюза, при одинаковом пороге содержания ГМ в пище значительно различается (от 25 до 600 м) (Y. Devos с соавт., 2009; L. Riesgo coaвт., 2010). Кроме расстояния между культурами и синхронности цветения, частота перекрестного опыления зависит от размера и ориентации полей (M. Langhof с соавт., 2010). В большинстве исследований распространения ГМ-сортов рассматривался один источник донорной пыльцы (D.I. Gustafson c coaвт., 2008; O. Sanvido с соавт., 2008), но позднее были созданы модели для множественных источников, рассчитанные по многочисленным результатам полевых экспериментов (А. Marceau с соавт., 2012). На основе данных о перекрестном опылении и подсчете пылыцы на различных расстояниях от источника рекомендован диапазон изолирующих расстояний от 10 до 200 м. Если обеспечить должное расстояние изоляции невозможно, участок реципиента и/или донора может быть окаймлен пыльцевым барьером. В поле-реципиенте пыльцевым барьером можно считать наружные ряды кукурузы. За пыльцевым барьером кукурузы шириной 10-20 м почти ни одна анализируемая выборка не содержит более 0,9 \% ГМ-материала. Для участков-реципиентов площадью менее 1 га и/или участков малой глубины может быть рекомендовано расстояние изоляции не менее 50 м, особенно в направлении розы ветров. Также рассмотрены результаты экспериментов по распространению ГМ-сортов кукурузы с пылыцой в странах Европы, Южной Америки, Африки, Азии и приведены рекомендации по безопасному совместному выращиванию нетрансформированных и ГМ-сортов кукурузы. Один из подходов для совместного безопасного выращивания ГМкукурузы с неГМ-кукурузой - использование растений с цитоплазматической мужской стерильностью (ЦМС), у которых пыльца дефектна или образуется в малых количествах. В обзоре дан анализ литературы по генетическому контролю ЦМС (Т-, S- и С-типов и форм, полученных с помощью CRISPR/Cas9 технологии) и истории попыток использования в практике сельского хозяйства явления ЦМС с момента его открытия до наших дней. При использовании гибридов кукурузы с

* Работа выполнена при финансовой поддержке РФФИ в рамках научного проекта № 18-29-14048мк и Программы фундаментальных научных исследований государственных академий наук на 2018-2020 годы (№ государственной регистрации АААА-А17-117102740101-5) (для авторов М.И. Чумакова и Ю.С. Гусева, ГМ-кукуруза: получение, полевые испытания). Спонсоры не участвовали в дизайне исследования, сборе и анализе данных, принятии решения о публикации или подготовке рукописи. 
ЦМС расстояния изоляции между соседними ГМ- и неГМ-полями кукурузы могут быть значительно сокращены (до 10 м) при сохранении соответствия европейским требованиям (порог маркировки $0,9 \%)$. Однако для практического массового выращивания ГМ-кукуруза с ЦМС пока не используется. В России еще предстоит выработать собственные меры и рекомендации по совместному выращиванию ГМ- и неГМ-кукурузы.

Ключевые слова: генетически-модифицированная кукуруза, поток генов, пыльца, ЦМС, возделывание ГМ-культур, законодательное регулирование.

Получение сортов генно-инженерными методами (ГМ) и их практическое применение активно развиваются как направления сельскохозяйственной биотехнологии с 1985 года. Крупномасштабное промышленное производство генно-модифицированных (ГМ) растений, в частности кукурузы, началось в 1996 году. Площади возделывания сельскохозяйственных ГМ-культур с начала их использования увеличились более чем в 100 раз с 1,7 млн га в 1996 году до 185 млн га в 2016 года, что составило около $12 \%$ мировых посевных площадей (1). В 2017 году ГМ-сорта с устойчивостью к гербицидам (отдельно либо в сочетании с резистентностью к насекомымвредителям) в мире выращивались в общей сложности на 166,4 млн га (2).

Кукуруза (Zea mays L.) - одна из наиболее распространенных сельскохозяйственных культур, производство которой в последние 10 лет в мире выросло с 600 до 1000 млн т. Она хорошо адаптируется к повышенным температурам, что в условиях потепления климата создает потенциал для расширения зон культивирования, в том числе в России, где, по данным Росстата, кукурузы в 2018 году было выращено почти в 9 раз больше, чем в 1995 году (http://www.gks.ru/free_doc/new_site/business/sx/val_1.xls). Cpeди ГМ-культур кукуруза вторая в мире после сои по площади посевов и первая - по сбору урожая. В 2015 году под ГМ-кукурузой было занято 53,6 млн га, или почти треть общей площади посевов культуры (185 млн га) в мире (3). То есть существует опасность переноса генов от ГМ-кукурузы в неГМ-кукурузу при их совместном выращивании.

Согласно Конвенции по биоразнообразию 1993 года (Convention on Biological Diversity, Unaited Nations 1992; вступила в силу в 1993 году), каждая страна-участница должна разработать стратегию и программу по сохранению и использованию своих биоресурсов с их гарантированным и безопасным воспроизводством (4). В частности, требуется установление и утверждение способов и методов регулирования, управления и контроля над рисками, связанными с созданием, использованием и распространением ГМ-сортов, а также разработка методов оценки возможных рисков при вырашивании ГМ-сортов для сохранения биоразнообразия (5).

Россия - одна из стран, в которых запрещено коммерческое выращивание ГМ-культур (Федеральный закон от 05.07.1996 № 86-Ф3 «О государственном регулировании в области генно-инженерной деятельности», Федеральный закон от 03.07.2016 № 358-Ф3 «О внесении изменений в отдельные законодательные акты Российской Федерации в части совершенствования государственного регулирования в области генно-инженерной деятельности»). Федеральный закон № 86-Ф3 (1996 год) изначально не предусматривал регистрацию ГМ-сортов и производство продукции на их основе, но уже 10 лет спустя в России прошли исследования и были разрешены для использования 15 ГМ-культур: 8 линий кукурузы, 3 - сои, 1 - сахарной свеклы, 1 - риса и 2 сортов картофеля (Онищенко Г.Г. «О совершенствовании надзора за пищевыми продуктами, содержащими ГМО и ГММ». Письмо Федеральной службы по надзору в сфере защиты прав потребителей и благополучия человека от 20 августа 2008 года № 01/9044-832). Действующий с 2018 года Ф3 РФ №358 также запрещает коммерче- 
ское использование ГМ-растений в сельском хозяйстве, но разрешает их выращивание и тестирование в научно-исследовательских целях. Следовательно, в России возникла реальная необходимость разработки критериев совместного безопасного выращивания нетрансформированных и ГМ-культур, в том числе кукурузы, с учетом задач по сохранению биоразнообразия. Такая разработка включает анализ мирового опыта экспериментальной оценки возможных рисков при выращивании ГМ-растений. Эта проблема имеет много различных аспектов, например учет влияния гербицидов и инсектицидов на нецелевые виды растений и насекомых при выращивании ГМ-культур (6), однако в своем обзоре мы сосредоточимся на оценке рисков распространения ГМ-кукурузы с пыльцой при совместном выращивании нетрансформированных и ГМ-сортов кукурузы, которое в условиях России не исследовалось.

Распространение пыльцы ГМ-кукурузы в полевых условиях. Кукуруза - однодомный ветроопыляемый вид, растения в высоту достигают 3 м (иногда до 6-7 м), в связи с чем повышается риск распространения пыльцы ГМ-сортов, переносимой ветром на десятки и сотни метров $(7,8)$. На перенос пыльцы влияют многие факторы: ветер (скорость и направление), дождь (влажность), физиология (жизнеспособность), количество пыльцы, характер ландшафта, размеры, форма и ориентация реципиентного поля, синхронность цветения донора и реципиента пыльцы (9).

Жизнеспособность пыльцы. Жизнеспособность пыльцы (способность прорастать) - важное условие для перекрестного опыления. После выхода из пыльников пыльца кукурузы жизнеспособна в течение 1-24 ч $(10,11)$. В условиях умеренного климата Европы (Франция) жизнеспособность пыльцы сохраняется до 24 ч (11). В зависимости от атмосферных условий в штате Айова (США) прорастание пыльцы уменьшалось на 50 \% через 14 ч (12). В многолетних исследованиях в засушливых условиях Мексики (местность Наярит) отмечали снижение жизнеспособности пыльцы на открытом воздухе на $80 \%$ за 1 ч и на $100 \%$ за 2 ч, в самых сухих условиях $100 \%$ зерен пыльцы стали нежизнеспособными в течение 1 ч (12).

Bemep. Воздушные потоки при распространении пыльцы могут поднять пыльцу высоко в атмосферу и распределить ее на значительные расстояния. Жизнеспособность пыльцы с высотой снижается, но на больших высотах пониженная температура воздуха благоприятствует поддержанию жизнеспособности пыльцы. Основной горизонтальный поток пыльцы у кукурузы отмечали на высоте 6,5 м, и он был одинаковым на расстоянии 3-10 м от источника (13). Небольшое количество пыльцы регистрировали на расстоянии 800-1000 м от источника, при этом скорость оседания пыльцы колебалась в пределах 0,0002-0,001 зерен/( $\left.{ }^{2} \cdot \mathrm{c}\right)(13,14)$. В среднем частота перекрестного опыления (\% зерен) была одинаковой на расстоянии 28 м по ветру и на расстоянии 10 м против ветра (15).

Скорость ветра - основная переменная величина, определяющая количество рассеиваемой пыльцы после выброса пыльцевых зерен из пыльников. Время и расстояние падения пыльцевого зерна на рыльце растения-реципиента зависят от силы тяжести, с одной стороны, и турбулентности и силы воздушных потоков - с другой (16). Зерна пыльцы кукурузы по сравнению с пыльцой других опыляемых ветром видов относительно крупные (средний диаметр 90 мкм) и тяжелые $(0,25$ мкг), поэтому пыльца кукурузы имеет высокую скорость оседания $(14,17)$. Порядка 9599 \% пыльцы осаждается на расстоянии около 30 м от источника, на отдалении более 30-50 м ее количество значительно снижается, но четкого 
расстояния, дальше которого она не обнаруживается, нет $(13,14,17)$. Относительная плотность пыльцы в опытах в штате Массачусетс (США) падала примерно до $2 \%$ на расстоянии 60 м от края посевов культуры, и сохранялась в пределах 0,50-0,75\% на расстоянии 500 м от донорной культуры (18). В другой работе сообщатся о скорости оседания пыльцы по направлению ветра на расстоянии 10 м от источника $-10-100$ зе-

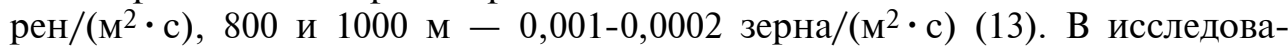
нии, проведенном в Мексике, отмечается отсутствие корреляции между скоростью ветра и процентом скрещиваний на участках, то есть роль скорости ветра может быть несущественной для частоты скрещиваний (8).

Влажность, дождь. В потоке воздуха пыльца может захватываться каплями воды и/или попадать на влажные цветки, где она лопается и погибает. Как правило, пыльца кукурузы высыпается из пыльников в сухих условиях, в основном с утра до полудня $(13,14)$. Когда идет дождь, высвобождение пыльцы задерживается, поскольку пыльники не растрескиваются во влажных условиях $(13,14)$. Однако опубликованных данных, позволяющих количественно оценить влияние дождя на раскрывание пыльников и поток пыльцы кукурузы, пока нет.

Размеры поля ГМ-источника пыльцы и поля-реципиента. Облако пыльцы растений-реципиентов над полем реципиента конкурирует с донорной пыльцой. Чем больше это поле, тем больше масса собственной пыльцы реципиента. Полевые испытания показали, что для донора пыльцы заданного размера частота перекрестного опыления уменьшаются по мере увеличения размера поля-реципиента $(14,19,20)$. Этот показатель, выраженный в процентах ГМ-растений, снизился с 1,8 до 0,8 \%, когда размер поля-реципиента пыльцы увеличился с 0,25 до 1 га (19). Результаты исследования с кормовой кукурузой в Германии, когда донорские поля ГМ-кукурузы были окружены изогенным неГМ-сортом, подтвердили эти результаты (14). Однако позднее в Германии установили, что размер полядонора 0,3-23 га не влиял на частоту перекрестного опыления (21). В опытах в Испании размер донорного поля кукурузы влиял на количество зерен ГМ-сорта, обнаруживаемых на поле-реципиенте, но в меньшей степени, чем размер поля-реципиента (22).

Форма и ориентация полей доноров и реципиентов пыльцы. Исследование влияния формы полей реципиентов и доноров пыльцы показали, что объемы их перекрестного опыления можно легко сократить, изменив квадратную форму поля-реципиента на прямоугольную той же площади и расположив его соответствующим образом $(14,23)$. Например, если полереципиент площадью 5 га было обращено к источнику пыльцы длинной стороной, частота перекрестного опыления составляла $10,7 \%$, если короткой - только $3,4 \%$ (24).

Синхронность иветения донора и реципиента. Синхронизация рассеивания пыльцы и выбрасывания рылец имеет решающее значение для определения степени выживания пыльцы кукурузы $(14,25)$. Чем лучше синхронность между цветением донора пыльцы и выпуском рылец растения-реципиента, тем выше вероятность перекрестного опыления $(11,14$, $25,26)$. Разные сроки посева могут привести к разнице во времени цветения, ограничивая перекрестное опыление. В Испании разница в сроках посева в среднем на 1 нед снизила частоту перекрестного опыления в первом ряду полей-реципиентов на $50 \%$, на 3 нед - на $75 \%$ (20, 27). В средиземноморских европейских странах такой подход можно применять без потерь урожая $(20,27)$.

Барьеры для пыльцы. В качестве барьеров могут действовать расте- 
ния вокруг источника или реципиента пыльцы. Так, наличие нескольких рядов более рослых растений на внешней стороне поля-донора снижает частоту скрещиваний, то есть по эффекту аналогично увеличению расстояния до растений-реципиентов. Кроме того, барьеры привносят конкурирующую пыльцу, если это растения того же вида, и/или физически препятствуют переносу пыльцы по воздуху за счет воздействия на потоки и фильтрации $(18,28)$. Барьер из кукурузы и деревьев уменьшал перекрестные опыления (сразу за барьером) на 50 \% более эффективно, чем незасеянная земля (14). Барьер из высокорослого растения сорго уменьшил безопасное расстояние совместного выращивания ГМ- и неГМ-кукурузы с 35 до 20 м при пороговом значении частоты переопыления ниже 0,9 \% (29).

Влияние ландшафта. Весьма разнообразный характер ландшафтов Европейского союза (ЕС) предполагает, что меры по обеспечению сосуществования ГМ- и неГМ- растений должны быть адаптированы к региональным условиям согласно программе SIGMEA по устойчивому внедрению ГМ-культур в европейское сельское хозяйство). В 2010 году сравнили четыре различных по ландшафту зоны выращивания кукурузы в Эльзасе и Арагоне (Франция) и классифицировали региональные ландшафты по степени риска для различных пороговых значений $-0,1 ; 0,4$ и 0,9\% (30).

Анализ рисков распространения ГМ-сортов кукурузы с пыльцой в различных странах. Eвpona. Cmpaны EC. В Европейском Союзе действует Директива 2001/18/ЕС от 12 марта 2001 года о преднамеренном выпуске в окружаюшую среду генетически модифицированных организмов, которая в 2015 году была существенно скорректирована. Директива 2015/412/ЕС закрепила право государств - членов ЕС ограничивать или запрещать выращивание ГМО, прошедших процедуру одобрения в ЕC, на своей территории. Запрет можно ввести не только по научным, но и по политическим, социально-экономическим причинам. Разрешение на выращивание ГМ-культуры может быть получено только после индивидуальной оценки потенциальной опасности каждого ГМО для здоровья человека животных.

Исследование в 2000-2003 годах в 15 графствах Англии показало быстрое снижение темпов перекрестного опыления у кукурузы на расстоянии первых 20 м от донорной культуры, однако маркерные гены ГМ-сортов кормовой и сладкой кукурузы обнаружили методом ПЦР на расстояниях 80 и 200 м $(31,32)$. SCIMAC (Supply Chain Initiative on Modified Agricultural Crops, Великобритания) - организация, учрежденная для регуляции использования ГМ-растений в Англии при производстве сельскохозяйственной продукции, рекомендовала разделяющее расстояние 80 м при совместном выращивании ГМ- и неГМ-сортов кукурузы (31).

В связи с включением 8 сентября 2004 года 17 ГМ-сортов кукурузы в каталог разновидностей сельскохозяйственных растений в ЕС ожидалось увеличение коммерческих посевных площадей трансгенной кукурузы в некоторых странах (14) и установлены пороговые значения $(0,9 \%)$ допуска случайного и технически неизбежного присутствия ГМ-материала в продукции, не являющейся ГМ. Для уменьшения рассеивания пыльцы ЕС утвердил регламент, в котором 200 м устанавливается в качестве минимальной изоляции между источником пыльцы и полем-реципиентом (с использованием физических барьеров - 100 м) (14). При этом расстояния, исходно предложенные государствами - членами ЕС для обеспечения изоляции обычной и ГМ-кукурузы, варьировали от 15 до 800 м (33).

Разработана эмпирическая одномерная модель потока генов, опосредованного пыльцой кукурузы, которая позволила установить практику 
выращивания ГМ и традиционных растений при сохранении порогового значения 0,9 \% для ГМ-зерна в неГМ-зерне (34). На основании модели, описывающей снижение скорости прорастания пыльцевых зерен в атмосфере, можно предположить, что уменьшение скорости оседания сопровождается снижением жизнеспособности пыльцы (35). Простая дисперсионная модель предложена для иллюстрации возможных последствий изменения скорости осаждения и скорости прорастания для распространения пыльцы и перекрестного опыления кукурузы. Результаты показывают, что современные модели распространения пыльцы, которые не учитывают эти изменения, завышают показатели перекрестного опыления (35). Предложен подход к моделированию потока генов, опосредованного пыльцой из нескольких источников (8). Он основан на обобщенных линейных смешанных моделях, которые количественно оценивают изменчивость показателей по годам и местоположениям, чтобы определить, какие методы изоляции будут эффективно соответствовать порогу 0,9 \%. Данные для новой модели были получены из базы данных по экспериментам, проведенным в 2000-2010 годах в Германии, Испании, Италии, Канаде, Нидерландах, Польши, Румынии, Словакии, Франции и США. Согласно этой модели, для 1 га неГМ-поля, окруженного со всех четырех сторон ГМ-полями, достаточно 12 м пограничных рядов в сочетании с 12 м полосы под паром для обеспечения порогового значения $0,9 \%$ (на $95 \%$ уровне значимости), установленного ЕС (9). На основе сравнения четырех методов оценки наличия ГМ-кукурузы на полях неГМ-реципиентов с математической обработкой результатов был предложен более надежный способ регистрации ГМскрещиваний по всей глубине поля (36).

Выращивание ГМ-кукурузы в Европе до 2005 года ограничивалось Испанией (2004 год - около 58 тыс. га). С 2005 года ГМ-сорта кукурузы возделывались в Чешской Республике, Словакии, Франции, Германии, Португалии (36). Однако с 2008 года Франция запретила выращивать ГМ-сорт кукурузы MON810, устойчивый к насекомым-вредителям (33). Германия после дополнительных исследований и общественных дискуссий также запретила использование MON810 на своей территории (37). Посевы ГМ-кукурузы в Чешской Республике и Словакии с 2008 года только снижались вплоть до полного запрета в 2017 году (2). В Португалии и Испании в 2017 году площади под ГМ-кукурузой снизились на $10 \%$ относительно 2016 года (https://www.infogm.org/6391-europe-GMO-drop-of-transgenic-crops?lang=fr).

Италия. В Италии (Ломбардия) проведены эксперименты по изучению влияния разных сроков цветения ГМ-донора и неГМ-реципиента кукурузы на количество ГМ-растений в посевах реципиента. Установлено незначительное или полное отсутствие уменьшения потока пыльцы при разнице во времени цветения между источником и реципиентом до 3 сут. При 4-5 сут отмечали снижение потока пыльцы на $25 \%$, при 6 сут - на $50 \%$, более 7 сут - на $100 \%$. Порог перекрестного опыления $(0,9 \%)$ достигался при буферной зоне 25 м, при этом эффективным барьером были растения кукурузы, а не паровые земли (38).

Румыния. В 2008-2009 годах на юге (округ Калараси), востоке (округ Брайла) и западе (округ Тимис) Румынии для оценки потенциального риска изучили распространение пыльцы ГМ-сорта кукурузы MON810 (42). Участок размером $300 \times 250$ м с высаженными трансгенными растениями был окружен посевами нетрасгенных. Среднее расстояние, на котором содержанием ГМ-зерен было менее 0,9 \%, по всем четырем направлениям (север, юг, восток, запад) составило 20 м в 2008 году, 25 м - в 2009 году (39). Исходя из этого, для пространственной изоляции коммерческих ГМ- 
сортов авторы посчитали достаточным расстояние 35 м. В 2016 году Румыния прекратила выращивание ГМ-кукурузы (2).

Нидерланды. В 2006-2007 годах в трех регионах Голландии провели полевые испытания эффекта двух изолирующих расстояний (25 и 250 м), указанных в резолюции Dutch Coexistence Committee (Голландия) (40). Поле с ГМ-донором (модифицированный вариант DKC3421YG сорта MON810, 1 га) окружали в четырех направлениях полями (по 0,25 га) обычной кукурузы (сорт DKC3420), расположенными на расстоянии 25 и 250 м. ПЦРанализ показал наличие 0,080-0,084 \% ГМ-зерен в случае 25 м и 0,005$0,007 \%$ - для $250 \mathrm{м.}$

Отметим, что в странах Европейского союза принята более строгая нормативная база для ГМ-растений по сравнению с другими странами (41), при том, что в Европе выращивается меныше ГМ-кукурузы, чем на всех других континентах, кроме Австралии, хотя, по мнению итальянских ученых, проанализировавших 1783 публикации за период с 2002 по 2012 год, не выявлено прямой угрозы от использования ГМ-растений (42). Директива 2015/412/ЕС Европейского парламента и Совета от 11 марта 2015 года, как уже отмечалось, позволяет членам ЕС полностью самостоятельно определять объемы и регламенты выращивания ГМ-растений (43). К октябрю 2015 года 19 из 28 стран ЕС подали заявки на отказ от выращивания ГМ-кукурузы MON810 (44), к 2017 году этот сорт выращивали только Португалия и Испания (45).

Россия. В 2012 году в Российской Федерации утверждена Комплексная программа развития биотехнологий (в том числе сельскохозяйственной биотехнологии) на период до 2020 года (46). В 2013 году Россия занимала 12-е место в мире по производству зерна кукурузы (47). По данным Росстата, в 2016 году сбор зерна кукурузы был почти в 9 раз выше, чем в 1995 году (соответственно 15,0 млн т против 1,7 млн т), но за последующие 2 года снизился, составив в 2017 году 13 млн т, в 2018 году 11 млн т (http://www.gks.ru/free_doc/new_site/business/sx/val_1.xls). При этом посевная площадь под кукурузой в период с 1995 по 2018 год в России, по данным Росстата, увеличилась почти в 4 раза (с 643 тыс. га до 2452 тыс. га) (http://www.gks.ru/free_doc/new_site/business/sx/posev_pl1.xls).

В настоящее время ГМ-кукуруза на территории России официально не выращивается, хотя в 2008 году были готовы для массового производства 8 линий ГМ-кукурузы американского происхождения (Онищенко Г.Г. «О совершенствовании надзора за пищевыми продуктами, содержащими ГМО и ГММ». Письмо Федеральной службы по надзору в сфере защиты прав потребителей и благополучия человека от 20 августа 2008 года № 01/9044-8-32).

Для сравнения, площадь мировых посевов биотехнологических культур увеличилась с 1,7 млн га в 1996 году до 189,8 млн га в 2017 году (более чем в 100 раз) (48). В 2016 году общий мировой доход фермеров от использования ГМ-кукурузы составил 2,1 млрд USD, совокупный доход за 1996-2016 годы - 13,1 млрд USD, из них 4,5 млрд USD (34 \%) были обусловлены увеличением доходности, остальная часть - снижением себестоимости продукции (49).

В обзоре А.А. Жученко (50) приведен анализ рисков, связанных с созданием, выращиванием и использованием ГМ-растений в сельском хозяйстве. Рассмотрены ограничения генетической инженерии, а также возможные эволюционные, биологические и экологические последствия широкого использования генетически модифицированных организмов. Отметим, что некоторые ограничения и опасности генетической инженерии, 
упомянутые в обзоре (в частности, отсутствие методов сайт-направленной интеграции генов, или вставки интродуцируемых генов в определенный сайт ДНК хозяина), уже преодолены современными CRISPR/Cas-технологиями. При моделировании микроэволюции популяции, в которую попали ГМ-особи, Л.А. Животовским (51) рассмотрены два сценария поведения смешанных популяций в зависимости от адаптационного потенциала ГМособей. Согласно одному из сценариев, ГМ-растения, несущие полезные приспособления (например, жаро- и солеустойчивость), могут получить преимущество в течение короткого срока перед другими популяциями и вытеснить их, но потом погибнуть из-за собственной узкой адаптации при значительном и разнообразном изменении условий («гипотеза троянского коня»). К подобным выводам ранее пришли и другие авторы (52). Однако экспериментальная оценка рисков распространения ГМ-кукурузы в условиях России не проводилась, критерии и рекомендации для ее безопасного выращивания совместно с нетрансформированными сортами в условиях России отсутствуют.

Северная Америка. Мексика. Мексика считается центром происхождения и биоразнообразия кукурузы, доместификация которой началась на ее территории более 8 тыс. лет назад (53). В Мексике создано и хранится более 9 тыс. сортообразцов (54), популяции подвидов кукурузы (Zea mexicana, Z. parviglumis) и виды растения теосинте, которые участвовали в селекции современной кукурузы в Мексике (55).

Уже в 2001 году на севере Мексики (штат Оахаса) в местных популяциях кукурузы обнаружили ГМ-кукурузу, завезенную из США (56), хотя в более позднем 2-летнем исследовании 125 полей штата Оахаса с помощью метода ПЦР ГМ-кукурузу не выявили (57). Однако при этом анализировали не более 10 растений (початков) с каждого поля и использовали объединенные пробы образцов (от 300 до 810 и даже 5630) (57). Авторы также не указывают, на каком расстоянии находились исследуемые поля от полей, где в 1998 году в Мексике испытывали ГМ-сорта кукурузы. Экспериментальная проверка способности донорной пыльцы кукурузы распространяться и опылять растения-реципиенты в условиях Мексики показала наибольшую частоту скрещивания вблизи источника пыльцы $-12,9 \%$ на расстоянии 1 м. Этот показатель резко снижался до 4,6; 2,7; 1,4; 1,0; 0,9; 0,5 и $0,5 \%$ по мере увеличения расстояния соответственно до $2,4,8,12$, 16,20 , и 25 м. На расстоянии более 20 м частота скрещивания во всех точках были ниже 1 \% (8). Следует отметить, что в Мексике в отличие от многих других стран имеется дополнительный фактор повышенного риска неконтролируемого распространения ГМ-кукурузы: при выращивании этой культуры мелкие фермеры традиционно обмениваются зерном для посева, а также высевают смешанные популяции кукурузы (так называемая креолизация) (58). Моделирование распространения в Мексике ГМкукурузы в описанных условиях показало, что при засеве ею 5 га в каждом из 13 регионов через 10 лет ГМ-растения будут присутствовать в 87,85\% всех посевов (55).

Для защиты генетических ресурсов кукурузы в Мексике в 2008 году был разработан закон о биобезопасности ГМ-организмов, который предполагает создание зон изоляции районов, которые считаются центрами происхождения кукурузы; охрану видов, для которых Мексика считается центром происхождения и генетического разнообразия; использование изолирующих расстояний (250 м) для экспериментальных полевых исследований с трансгенной кукурузой, с дополнительными ограничениями в регионах, идентифицированных как центры происхождения (8). С 1996 
года Мексика одобрила 170 биотехнологических культур для производства продуктов питания, кормов и выращивания, в том числе 75 линий ГМкукурузы (2). В 2017 году Мексика утвердила для производства пять линий ГМ-кукурузы.

США. Существует заметный разрыв между американским и европейским подходами к выращиванию ГМ-культур. США имеют в 1,4 раза больше пахотных земель, чем ЕС, при этом выделяют почти в 600 раз больше земель для ГМ-культур (45). Эта огромная разница отражает разное отношение к генетически модифицированным организмам (ГМО) в Европе и США. В Европе и Америке в основу регулирования положены принципиально разные модели оценке рисков, присущих ГМО. Эти подходы получили название процесс-ориентированного (principle-based) и продукт-ориентированного (product-based) (59). В первом случае рисковый характер признается за процессом генетической модификации, во втором за ее результатом, объектом (ГМО или производной продукцией) (60). Законодательства всех стран можно разделить по этому критерию на два типа. К первому относится регулирование в ЕС, ко второму - в США и Канады. Большинство стран, которые придерживаются процесс-ориентированного подхода, участвуют в Картахенском протоколе по биобезопасности (Cartagena Protocol on Biosafety, 2000 год), а страны, реализующие продукт-ориентированный подход, в основном в нем не участвуют. Это обусловливает существенные различия в требованиях к ГМ-культурам, но напрямую не влияет на возможность их выращивания. Процесс-ориентированный подход воспринят в Бразилии и Индии, которые входят в число лидеров по использованию биотехнологий в сельском хозяйстве (61).

В США с 1986 года действуют Координационные рамки регулирования биотехнологии (Coordinated Framework for Regulation of Biotechnology), уточненные в 1991 году. Они служат руководством для федерального надзора и регулирования в области ГМ-продуктов, включая ГМ-культуры, пищевые продукты, применение ГМО. При осуществлении регулирования уполномоченные органы США должны основываться исключительно на рисках, присущих конечному продукту, без учета биотехнологических процессов его изготовления (62). В США нет федерального законодательства по ГМО, и США не является участником Картахенского протокола по биобезопасности и Конвенции о биологическом разнообразии (2).

Первая коммерческая гербицид-устойчивая ГМ-кукуруза появилась на рынке США в 1998 году. К 2009 году на долю генетически модифицированной кукурузы в США приходилось 85 \% (63). По оценке американских исследователей, урожайность ГМ-кукурузы с 1996 по 2010 год в центральном кукурузном поясе США лишь слегка увеличилась, в отличие от ГМ-сои. Но стало ли это следствием использования ГМ-кукурузы или действия других факторов, детально не проанализировано (64). Законодательство США в отношении ГМ-растений самое либеральное, хотя для США существует теоретическая опасность скрещивания кукурузы с гамаграссом восточным Tripsacum dactyloides L., который широко распространен в восточной и северной части США (65). Гамаграсс восточный принадлежит к тому же роду семейства Poaceae, что и кукуруза Zea mays L., и произрастает естественным образом в том же регионе США, где коммерчески производится кукуруза. Для исследования потока генов от кукурузы к гамаграссу были произведены экспериментальные скрещивания между между трансгенной кукурузой, используемой в качестве мужского родителя, и гамаграссом в качестве женского с целью оценить возможность межвидовой гибридизации (66). Никаких доказательств потока генов из транс- 
генной кукурузы в гамаграсс восточный в природе не наблюдали, хотя эти два вида росли в непосредственной близости в течение многих лет и имели широкие возможности для скрещивания (66).

Южная Америка. Колумбия. Колумбийский сельскохозяйственный институт (Instituto Colombiano Agropecuario, ICA) в 2010 году установил требование о расстоянии 500 м между местными и трансгенными полями кукурузы (67). В 2015 году в Колумбии проанализировали 60 случайно выбранных участков кукурузы в долине Сан-Хуан, посаженных группами на расстояниях 2,2-4 км на территории размером $15 \times 8$ км. Площади участков обычной кукурузы варьировали от 8 до 114 га, ГМ-кукурузы - от 95 до 125 га. Последствия распространения ГМ-кукурузы с пыльцой анализировали тремя независимыми методами (два иммуноферментных и ПЦР). Результаты показали наличие трансгенных последовательностей в листьях (более $88 \%$ участков) и семенах (12\% участков) неГМ-кукурузы (68).

Уругвай. В правительственных постановлениях Уругвая предусматривается, что при выращивании ГМ-кукурузы как минимум 10 \% площади должно быть занято неГМ-кукурузой в качестве зоны безопасности биоразнообразия. В резолюциях правительства (2003-2004 годы) установлено минимальное расстояние 250 м между ГМ- и неГМ-кукурузой (16). В 2010 году в Уругвае изучили случаи и определили частоту перекрестного опыления между коммерческими ГМ- и неГМ-сортами. Методология включала детекцию ГМ-сортов методами «сэндвич»-ELISA и ПЦР. Доля трансгенных проростков в потомстве неГМ- культур составила 0,56; 0,83 и $0,13 \%$ в трех точках отбора проб на расстоянии соответственно 40, 100 и 330 м от ГМ-культур (16).

Аргентина. Аргентина - третья страна в мире по объемам возделывания ГМ-культур (69). В 2010 году их посевные площади ГМ-культур здесь составляли $21 \%$ мировых посевов биотехнологических культур (для сои от общей площади посевов в стране $99 \%$, для кукурузы $-83 \%$, для хлопка - 94 \%) (70). В 2016 году этот показатель составил уже $97 \%$ для кукурузы, почти $100 \%$ для сои и $95 \%$ для хлопка (3).

Данные об экологических и агротехнических рисках, полученные в странах ЕС на основании проведенных оценок, и необходимость иметь определенные изолирующие зоны воспринимается в Аргентине как препятствие реализации национальных интересов (52), поскольку применение ГМ-культур в Бразилии и Аргентине позволило получить более высокий средний доход фермеров. Совокупный экономический эффект в размере 24,8 млрд USD для Бразилии и 21,1 млрд USD для Аргентины был достигнут в основном за счет снижения затрат на селективный гербицид и достижения более высокой урожайности (3).

Бразилия. С тех пор как в Бразилии в 1998 году была выращена первая ГМ-культура, их доля в посевах возросла до 88 \% для кукурузы, $96 \%$ для сои и 78 \% для хлопковых культур (3). В Бразилии требуется буферное расстояние в 100 м от края поля с ГМ-кукурузой до начала поля с неГМ-кукурузой. В качестве альтернативы можно использовать 20-метровый буфер, состоящий минимум из 10 рядов неГМ-кукурузы по краю поля ГМ-кукурузы. Буферные зоны были установлены Национальной технической комиссией по биобезопасности (Brazilian National Technical Biosafety Commission) на основе исследований потока генов, а также с учетом национального законодательства, которое установило порог в 1 \% для ГМкультур (71).

Африка. По сравнению с другими африканскими странами ЮжноАфриканская Республика с самого начала приняла биотехнологию ГМ- 
сельскохозяйственных растений. Первые полевые испытания ГМ-культур были проведены в ЮАР в 1989 году, первый коммерческий выпуск ГМкукурузы был утвержден в 1997 году (46). Основное законодательство в ЮАР, касающееся ГМО, включая их ограниченное использование, пробный выпуск, коммерческий выпуск, а также импорт и экспорт - это Закон 1997 года о ГМО (Genetically Modified Organisms Act No. 15 of 1997, Statutes of the Republic of South Africa - Agriculture) (46). В настоящее время ЮАР - восьмой производитель ГМО-культур в мире. Изучение уровня перекрестного опыления между ГМ- и неГМ-кукурузой в ЮАР показало, что на расстояние 45 м долетает $<0,1-1,0 \%$ пыльцы, на 145 м $-<0,01-$ $0,1 \%)$, на 473 м $-<0,01-0,001 \%$ (72).

Азия. Китай и Япония. При пороге $0,9 \%$ расстояние для изоляции в условиях Китая было оценено как 50 и 25 м по двухступенчатой модели (73). Японские правила маркировки пищевых продуктов для ГМ-продуктов не особенно строгие. Выращивание новых сортов ГМ-культур происходит на изолированных сельскохозяйственных угодьях. После того, как доказана безопасность таких сортов, их разрешается выращивать на обычных фермах. Однако в Японии внедрение ГМ-культур для производства пищевых продуктов встречает сильное противодействие со стороны общественности. Более 70 \% опрошенных японских потребителей против выращивания ГМ-сортов и употребления их в пищу (74).

Использование сортов кукурузы с мужской стерильностью для ограничения распространения кукурузы с пыльцой. Одним из подходов для совместного безопасного выращивания ГМ- и неГМ-кукурузой представляется использование растений с цитоплазматической мужской стерильностью (ЦМС), у которых пыльца дефектна (функционально неполноценна) или образуется в малых количествах. ЦМС наследуется по материнской линии. Сначала были известны три типа ЦМС: Т-тип (техасский), S-тип (USDA) и С-тип (чарруа тип) (75, 76). В 1990-х годах было установлено, что митохондриальный ген кукурузы T-urf13 кодирует небольшой белок URF-13 (13 кДа), экспрессирующийся в кристах митохондрий, который отвечает за Т-тип ЦМС у кукурузы, но также повышает восприимчивость к грибным патогенам $(76,77)$. Митохондриальный геном мужской стерильной S-цитоплазмы кукурузы содержит повторяющуюся R-область ДНК, имеющую две открытых рамки считывания (76). Восстановление фертильности ЦМС S-типа в основном контролируется ядерным восстановителем $R f 3$, который находится во 2-й хромосоме (78). Для ЦМС С-типа $R f 4$, расположенный в 8-й хромосоме, является доминантным геном восстановления фертильности (79).

Т-тип ЦМС широко присутствовал в гибридах кукурузы в Северной Америке в 1950-1960-х годах, в основном для ограничения самовоспроизводства семян фермерами (76). При этом для внедрения ЦМС-кукурузы в сельскохозяйственную практику было необходимо обеспечить сопоставимые урожаи. Однако погодные условия в начале 1970-х годов способствовали развитию фитофтороза листьев у сортов кукурузы с Т-типом ЦМС, что привело к потере до $15 \%$ урожая в штатах «кукурузного пояса» США (более 6 млрд USD по текущему курсу). Сорта без Т-типа ЦМС были невосприимчивы к инфекции, что ограничило использование ЦМС практике (80). Из-за восприимчивости Т-типа ЦМС к pace гриба Bipolaris maydis (ранее известной как Helminthosporium maydis, paca Т) был осуществлен поиск других групп цитоплазмы, обеспечивающих ЦМС кукурузы. В США в потомстве сорта Теороd (Айова) обнаружили ЦМС S-типа (часто его называют USDA-тип) (76). С-тип ЦМС, выявленный в бразиль- 
ском сорте кукурузы Charrua в 1970-м году, использовали при создании гибридов, но С-тип ЦМС оказался чувствителен к pace C B. maydis, обнаруженной пока только в Китае (76).

При оценке того, надежно ли ЦМС гибридов кукурузы уменышает поток генов из ГМ-растений, опосредованный пыльцой (81), в трех областях Германии проводили 2-летние полевые эксперименты с тремя гибридами кукурузы с ЦМС. Исследовали характеристики метелок, жизнеспособность пыльцы и частоту перекрестного опыления. Стабильность ЦМС зависела от генотипа, погодных условий года и местоположения. Один гибрид кукурузы ЦМС показал высокую стабильности ЦМС-С и очень низкую скорость перекрестного опыления $(<1 \%)$. Два других гибрида с типами ЦMC S и T характеризовались высокой изменчивостью и формировали фертильные метелки соответственно с небольшим или большим количеством пыльцы. У всех гибридов кукурузы с ЦМС перекрестное опыление было на 84-99 \% ниже, чем у обычного полностью фертильного сорта. Установлено, что при использовании гибридов кукурузы с ЦМС расстояния для изоляции между соседними ГМ- и неГМ-полями можно сильно сократить (до 10 м) при сохранении установленного порога 0,9 \% (81).

Если гибрид кукурузы с ЦМС и растение-опылитель обеспечивают другой генетический фон, урожайность может быть значительно повышена. Так называемый Plus-Hybrid-Effect сочетает потенциальные преимущества ЦМС и Хеnia-эффект (увеличение женской фертильности, связанное с перераспределением ресурсов или большей жизнеспособностью семян) (8183). В обзоре X. Wan с соавт. (84) обобщены основные достижения в идентификации и характеристике генов ЦМС у кукурузы, арабидопсиса и риса. В частности, у кукурузы до настоящего времени охарактеризовано 17 генов ЦМС, 13 из которых - ортологи генов ЦМС риса и/или арабидопсиса.

В 1998 году фирма «DuPont» (США) разработала ГМ-линии DP-321381 (коммерческое название 32138 SPT maintainer), РН-ØØØ676-7, РН-ØØØ6789, РН-ØØØ68Ø-2, а компания «Bayer CropScience» (США) представила ГМлинии ACS-ZMøØ1-9 (коммерческое название InVigor ${ }^{\mathrm{TM}}$ Maize) и ACSZMøØ5-4 (коммерческое название InVigor ${ }^{\mathrm{TM}}$ Maize), одобренные для коммерциализации ISAAA (GM Approval Database, http://www.isaaa.org/gmapprovaldatabase/default.asp). Линия DP-32138-1 (коммерческие выращивания в США в 2011 году и в Бразилии в 2015 году) имеет перенесенные гены ms45 (восстанавливает фертильность за счет нормализации развития клеточной стенки микроспор), zm-aal (при экспрессии в незрелой пыльце гидролизует крахмал и делает пыльцу стерильной) и маркерный ген $d s R e d 2$, кодирующий красный флуоресцентный белок для облегчения селекции. Линии РН-ØØØ678-9, РН-ØØØ676-7 и РН-ØØØ68Ø-2 (коммерческое выращивание в США в 1998 году) имеют перенесенный ген dam, который обеспечивает ЦМС, препятствуя образованию функциональных пыльников и пыльцы, и ген pat устойчивости к фосфинотрицину. Линии ACS-ZMØØ1-9 и ACS-ZMØØ5-4 имеют перенесенный ген barnase (вызывает мужскую стерильность; слит с тапетум-специфическим промотором ТА29 и активируется в ткани при формировании пыльцы, продукт обладает рибонуклеазной активностью, блокируя синтез РНК в клетках тапетума пыльника), ген bla (нейтрализует $\beta$-лактамные антибиотики, такие как ампициллин) и ген bar (в его присутствии вырабатывается фермент фосфинотрицин-Nацетилтрансфераза, который ацетилирует гербицид фосфинотрицин по аминогруппе, что делает его нетоксичным для растения).

В 2016 году компания «DuPont Pioneer» (США) разработала систему производства гибридных семян с использованием мужской стерильно- 
сти для получения гибридов кукурузы и других перекрестноопыляющихся культур (85). Основной элемент этой системы - так называемая технология производства семян (Seed Production Technology, SPT), которая включает несколько этапов. Сначала с помощью вектора, несущего конструкцию SPT (содержит ген мужской фертильности дикого типа Ms45 для восстановления фертильности, ген летальности пыльцы $Z m A A$, нарушающий ее нормальное развитие, и ген флуоресцентного маркера $D s R e d 2$, что облегчает сортировку семян), методом агробактериальной трансформации незрелых зародышей кукурузы получают трансгенную линию SPT transgenic maintainer line. Когда мужская стерильная линия (с мутантным геном $m s 45 / m s 45$ ) опыляется пыльцой линии, содержащей SPT-конструкцию, почти $100 \%$ полученных семян имеют генотип $m s 45 / m s 45$ и могут использоваться в качестве женских линий с ЦМС для скрещивания и получения гибридных семян. Чтобы ограничить скорость передачи трансгена через пыльцу линий, содержащих SPT-конструкцию, была разработана система производства гибридных семян Multi-Control Sterility (MCS). Трансгенную линию получают методом агробактериальной трансформации мутантов по генам $m s 7$ или $m s 30$ с использованием вектора, содержащего ген мужской фертильности $(\mathrm{ZmMs})$ для восстановления фертильности, два гена нарушения фертильности пыльцы, которые способны ингибировать образование или функционирование трансгенной пыльцы, флуоресцентный маркерный ген (DsRed2) и ген устойчиврсти к гербицидам (bar) для предотвращения загрязнение семян (86). У линий, содержащих эти конструкции, скорость передачи трансгена значительно снижается.

В 2014 году фирма «Monsanto» (США) разработала систему Roundup Hybridization System (RHS) для производства гибридных семян (87). Mеханизм RHS основан на получении растений, устойчивых к этому гербициду благодаря введению гена CP4-EPSP из Agrobacterium sp. CP4, кодирующего 5-енолпирувил-шикимат-3-фосфат-синтазу, нечувствительную к глифосату, с последующим избирательным снижением экспрессии этого гена в мужских репродуктивных тканях. В результате при воздействии глифосатом образуется неполноценная пыльца (glyphosate-mediated male sterility) практически без отрицательных последствий для остальных органов (87).

Несмотря на то, что трехгенная гибридная система на основе ЦМС использовалась в коммерческом производстве гибридных семян ГМ-кукурузы, ее широкому применению помешали серьезные проблемы (84). Большинство разработанных стратегий ЦМС не были успешно применены из-за отсутствия рентабельной, экологичной и генетически стабильной стратегии крупномасштабного размножения родительских линий с ЦМС (84). Мы не обнаружили в доступной литературе данных о широкомасштабной продаже и выращивании семян ГМ-кукурузы с ЦМС, хотя в 2017 году вышло сообщение о коммерческом выращивании ГМ-рапса с ЦМС (2).

С 2016 года для создания линий кукурузы с ЦМС начала использоваться технология CRISPR/Cas9. K. Хie с соавт. (88) изучали ген ms33 кукурузы, кодирующий глицерол-3-фосфатацилтрансферазу (GPAT) - ключевой фермент в синтезе глицеролипида. Полученная с помощью технологии CRISPR/Cas9 форма оказалась полноценным мутантом с ЦМС без пыльников и зрелых пыльцевых зерен. Потеря экспрессии гена $Z m M s 33$ в пыльниках нарушает метаболизм и развитие тапетума, что приводит к повреждению кутикулы пыльника, блокированию образования пыльцы. В 2018 году создан вектор CRISPR/Cas9 для редактирования гена кукурузы $M S 8$, кодирующего $\beta-1,3$-галактозилтрансферазу, которая влияет на мейотическую стадию развития пыльника (89). Авторы получили восемь 
трансгенных линий $\left(\mathrm{T}_{0}\right)$. Результаты секвенирования показали, что гены $M S 8$ в этих линиях поколения $\mathrm{T}_{0}$ не мутировали. Однако были обнаружены мутации в гене $M S 8$ у потомков трансгенной линии H17 в $\mathrm{F}_{1}$ (получены при скрещивании с инбредной линией Zong31) и $\mathrm{F}_{2}$ (размножены самоопылением $\mathrm{F}_{1}$ ). Мутация в гене $M S 8$ и ЦМС могут стабильно наследоваться в поколениях и передаваться в другие элитные инбредные линии для получения гибридной продукции (89). С помощью технологии CRISPR/Cas9 также получены мутанты кукурузы по гену MS45, необходимому для развития пыльцы (90). Растения поколения $\mathrm{T}_{0}$, содержащие двуаллельные мутации по гену MS45, были с ЦМС. Линии с ЦМС, созданные с использованием технологии CRISPR/Cas9, пока не испытывались в практическом производстве. Таким образом, у кукурузы более полувека ЦМС используется для ограничения скрещивания донора и реципиента пыльцы, но этот подход пока по различным причинам не получил широкого применения для создания ГМ-кукурузы. Возможно, более успешными окажутся попытки создания сортов кукурузы с ЦМС с помощью технологии CRISPR/Cas9.

Ранние исследования потока генов при перекрестном опылении рассмотрены в обобщающих работах $(14,91)$. Однако различия в подходах, аналитических методах и схемах экспериментов препятствуют сравнению результатов и усложняют определение мер по ограничению перекрестного опыления в полевых условиях. В частности, расстояние между ГМ- и неГМ-кукурузой, рекомендуемое в странах ЕС при одинаковом пороге содержания ГМ в пище, значительно различается (от 25 до 600 м) (92, 93). Кроме расстояния между культурами и синхронности цветения, частота перекрестного опыления зависит от размера и ориентации полей (94). Большинство исследований распространения ГМ-сортов были основаны на одном источнике донорной пыльцы, часто с меньшим или равным размером поля относительно реципиента $(34,91)$. Позднее были созданы модели, основанные на множественных источниках пыльцы, рассчитанные на многочисленных данных полевых экспериментов (95). Установленные требования по минимальному расстоянию и времени цветения при выращивании трансгенной и нетрансгенной кукурузы дискриминируют мелких фермеров, а дополнительные затраты на выполнение этих требований (до 300 евро/га) серьезно ограничивают экономические выгоды производителей ГМ-кукурузы в Европе $(92,96)$.

Итак, со второй половины 1990-х годов площади под ГМ-кукурузой увеличились более чем в 100 раз, поэтому вопросы ее распространения и перекрестного опыления стали более актуальными в практическом аспекте. На основе данных о перекрестном опылении и подсчете пыльцы на различных расстояниях от источника рекомендован диапазон изолирующих расстояний от 10 до 50 м. Если обеспечить должное расстояние изоляции невозможно, участок реципиента и/или донора может быть окаймлен пыльцевым барьером. В поле-реципиенте, пыльцевым барьером можно считать наружные ряды кукурузы. После пыльцевого барьера кукурузы шириной 10-20 м почти ни одна анализируемая выборка не содержит более 0,9 \% ГМ-материала. Для участков-реципиентов площадью менее 1 га и/или участков малой глубины может быть рекомендовано расстояние изоляции не менее 50 м, особенно в направлении розы ветров. При использовании гибридов кукурузы с ЦМС расстояния изоляции между соседними ГМ- и неГМ-полями кукурузы могут быть значительно сокращены (до 10 м) при сохранении соответствия европейским требованиям (порог маркировки 0,9 \%). Однако для практического массового выращива- 
ния ГМ-кукуруза и измененная с помощью технологии CRISPR/Cas9 кукуруза с ЦМС пока не используется. В России еще предстоит выработать собственные меры и рекомендации по совместному выращиванию ГМ- и неГМ-кукурузы.

Авторы признательны О.В. Гуторовой за прочтение рукописи и высказанные замечания и благодарны Л.М. Федоровой за иенные замечания и обсуждение статьи. Мы также признательны рецензенту за конструктивные вопросы и предложения.

\title{
1ФГБУН Институт биохимии и физиологии растений и микроорганизмов РАН, \\ Поступила в редакцию \\ 21 января 2019 года
}

410049 Россия, г. Саратов, пр-т Энтузиастов, 13,

e-mail: chumakovmi@gmail.com $\bowtie$, gusev_yu@ibppm.ru;

${ }^{2}$ ФГБОУ ВО Саратовская государственная юридическая

академия,

410056 Россия, г. Саратов, ул. Вольская, 1,

e-mail: bog.junior@gmail.com, AYSockolov@mail.ru

Sel'skokhozyaistvennaya biologiya [Agricultural Biology], 2019, V. 54, № 3, pp. 426-445

\section{RISKS OF POLLEN-MEDIATED GENE FLOW \\ FROM GENETICALLY MODIFIED MAIZE DURING CO-CULTIVATION WITH USUAL MAIZE VARIETIES} (review)

\author{
M.I. Chumakov', Yu.S. Gusev', N.V. Bogatyreva², A.Yu. Sockolov² \\ ${ }^{1}$ Institute of Biochemistry and Physiology of Plants and Microorganisms RAS, 13, Prospekt Entuziastov, Saratov, \\ 410049 Russia, e-mail chumakovmi@gmail.com ( $₫$ corresponding author), gusev_yu@ibppm.ru; \\ ${ }^{2}$ Saratov State Law Academy, 1, ul. Volskaya, Saratov, 410056 Russia, e-mail bog.junior@gmail.com, AYSock- \\ olov@mail.ru
}

ORCID:

Chumakov M.I. orcid.org/0000-0002-6396-2851 Bogatyreva N.V. orcid.org/0000-0001-5778-5249

Gusev Yu.S. orcid.org/0000-0001-7379-484X Sockolov A.Yu. orcid.org/0000-0003-3350-7775

The authors declare no conflict of interests

Acknowledgements:

The authors are grateful to O.V. Gutorova for reading the manuscript and the comments made, and are grateful to L.M. Fedorova for valuable comments and discussion of the article. We are also grateful to the reviewer for the constructive questions and suggestions.

Supported financially in parts by the Russian Foundation for Basic Research (Project No. 18-29-14048mk) and the Program of Basic Research of State Academies, 2018-2020 (No. AAAA-A17-117102740101-5) for genetically modified corn development and field testing (allocated to M.I. Chumakov and Yu.S. Gusev). The funders had no role in study design, data collection and analysis, decision to publish, or preparation of the manuscript.

Received January 21, 2019 doi: 10.15389/agrobiology.2019.3.426eng

\section{Abstract}

Since 1985, active development of agricultural biotechnology has been associated with genetically modified (GM) plants. After the production of GM maize in the second half of the 1990s, the area of its crops has increased over 100-fold. Therefore, the GM maize spreeding and cross-pollination have become more practically relevant. Almost one third of the total area of all GM plants is occupied by GM maize. The Russian Federal Law No. 358 of 03.07 .2016 prohibits the commercial use of GM plants in agriculture but allows their cultivation and testing for research purposes. This necessitates assessing and developing criteria, currently absent in Russia, for the safe co-cultivation of non-GM and GM varieties. This review analyzes the factors influencing pollen dispersion: wind (speed and direction), humidity (rain), physiology (viability), the pollen amount, the character of the landscape, the size, shape and orientation of the recipient fields, and the synchrony of flowering of the pollen donor and recipient. Early studies of gene flow in crosspollination were reviewed Y. Devos et al., (2005) and O. Sanvido et al. (2008). In particular, the distance between GM and traditional maize recommended in the EU countries, with the same threshold for GM content in food, varies considerably (from 25 to $600 \mathrm{~m}$ ) (Y. Devos et al., 2009; L. Riesgo et al., 2010). In addition to the distance between crops and the synchronicity of flowering, the frequency of cross-pollination depends on the field size and orientation (M. Langhof et al., 2010). Estimates of the cross-pollination frequency and the pollen counts at different distances from the GM donor allowed the researchers to recommend isolation distances of 10 to $200 \mathrm{~m}$. If the isolation distance cannot be ensured, the recipient and/or donor field should be bordered by a barrier to pollen. In the recipient field, the outer rows of maize plants can be the barrier. After a 
10-20 m maize barrier, almost none of the analyzed samples contains more than $0.9 \%$ of GM material. For recipient fields of less than 1 ha in area and/or low-depth fields, an isolation distance of at least $50 \mathrm{~m}$ should be recommended, especially in the wind rose direction. Data on spreading GM maize with pollen in Europe, South America, Africa, and Asia provide recommendations for safe co-cultivation of non-GM and GM maize varieties and lines. The cytoplasmic male sterility (CMS) approach for GM- and non-GM maize co-cultivation was developed. The genetic control of CMS (N-, S-, C-types and CRISPR-mediated approach) and the CMS application history are discussed. For CMS hybrids, the isolation distances between GM and traditional maize crops may be significantly reduced (up to $10 \mathrm{~m}$ ) without violation of the European requirements of a $0.9 \%$ marking threshold. However, GM-maize with CMS is not used for practical cultivation. Russia has yet to develop its own measures and recommendations for the joint cultivation of GM and traditional maize.

GMO regulations.

Keywords: genetically modified corn, gene flow, pollen, CMS, GM crop co-cultivation,

\section{REFEREN CES}

1. Pellegrino E., Bedini S., Nuti M., Ercoli L. Impact of genetically engineered maize on agronomic, environmental and toxicological traits: a meta-analysis of 21 years of field data. Scientific Reports, 2018, 8(3113): 1-12 (doi: 10.1038/s41598-018-21284-2).

2. ISAAA. Global Status of Commercialized Biotech/GM Crops: 2017. Biotech Crop Adoption Surges as Economic Benefits Accumulate in 22 years. ISAAA Brief No. 53. ISAAA, Ithaca, NY, 2017.

3. ISAAA. Global Status of Commercialized Biotech/GM Crops: 2016. ISAAA Brief No. 52. ISAAA, Ithaca, NY, 2016.

4. Golikov A.G., Stepanova N.G., Krasovskii O.A., Skryabin K.G. Biotekhnologiya, 1997, 1: 53-58 (in Russ.).

5. Chesnokov Yu.V. Vavilovskii zhurnal genetiki i selektsii, 2011, 15(4): 818-827 (in Russ.).

6. Romeis J., Naranjo S.E., Meissle M., Shelton A.M. Genetically engineered crops help support conservation biological control. Biological Control, 2019, 130: 136-154 (doi: 10.1016/j.biocontrol.2018.10.001).

7. Bannert M., Stamp P. Cross-pollination of maize at long distance. European Journal of Agronomy, 2007, 27: 44-51 (doi: 10.1016/j.eja.2007.01.002).

8. Baltazar B., Castro Espinoza L., Espinoza Banda A., de la Fuente Marthnez J.M., Garzyn Tiznado J.A., González García J., Gutiérrez M.A., Guzmán Rodríguez J.L., Heredia Díaz O., Horak M.J., Madueco Martínez J.I., Schapaugh A.W., Stojšin D., Uribe Montes H.R., Zavala García F. Pollen-mediated gene flow in maize: implications for isolation requirements and coexistence in Mexico, the center of origin of maize. PloS ONE, 2015, 10: e0131549 (doi: 10.1371/journal.pone.0131549).

9. Marceau A., Gustafson D.I., Brants I.O., Leprince F., Foueillassar X., Riesgo L., Areale F.-J., Sowaf S., Kraicg J., Badeah E.M. Updated empirical model of genetically modified maize grain production practices to achieve European Union labeling thresholds. Crop Science, 2013, 53: 1712-1721 (doi: 10.2135/cropsci2012.04.0224).

10. Luna S., Figueroa J., Baltazar B., Gomez R., Townsend R., Schoper J.B. Maize pollen longevity and distance isolation requirements for effective pollen control. Crop Science, 2001, 41: 15511557 (doi:m10.2135/cropsci2001.4151551x).

11. Angevin F., Klein E., Choimet C., Meynard J., de Rouw A., Sohbi Y. Modélisation des effets des systumes de culture et du climat sur les pollinisations croisŭes chez le mans. Isolement des collectes et maotrise des dissŭminations au champ. In: Rapport du groupe 3 du programme de recherche: pertinence ŭconomique et faisabilitŭ d'une filiure sans utilisation d'OGM, INRAFNSEA. J.-M. Meynard, M. Le Bail (eds.). Thiverval-Grignon, France, 2001: 21-36.

12. Aylor D. Survival of maize (Zea mays) pollen exposed in the atmosphere. Agricultural and Forest Meteorology, 2004, 123: 125-133 (doi: 10.1016/j.agrformet.2003.12.007).

13. Jarosz N., Loubet B., Durand B., Foueillassar X., Huber L. Variations in maize pollen emission and deposition in relation to microclimate. Environmental Science \& Technology, 2005, 39: 4377-4384 (doi: 10.1021/es0494252).

14. Devos Y., Reheul D., De Schrijver A. The co-existence between transgenic and non-transgenic maize in the European Union: a focus on pollen flow and cross-fertilization. Environmental Biosafety Research, 2005, 4(2): 71-87 (doi: 10.1051/ebr:2005013).

15. Ma B.L., Subedi K.D., Reid L.M. Extent of cross-fertilization in maize by pollen from neighboring transgenic hybrids. Crop Science, 2004, 44: 1273-1282 (doi: 10.2135/cropsci2004.1273).

16. Galeano P., Debat C.M., Ruibal F., Fraguas L.F., Galván G.A. Cross-fertilization between genetically modified and non-genetically modified maize crops in Uruguay. Environmental Biosafety Research, 2010, 9(3): 147-154 (doi: 10.1051/ebr/2011100).

17. Aylor D., Schultes N., Shields E. An aerobiological framework for assessing cross-pollination in maize. Agricultural and Forest Meteorology, 2003, 119: 111-129 (doi: 10.1016/S0168-1923(03)00159-X). 
18. Emberlin J., Adams-Groom B., Tidmarsh J. A report on the dispersal of maize pollen. In: $R e-$ port commissioned by and available from the Soil Association National Pollen Research Unit. Bristol House, Bristol, UK, 1999: 40-56.

19. Mele E. Spanish study shows that coexistence is possible. Agricultural Biotechnology International Conference, 2004, 3: 2.

20. Ortega Molina J. Results of the studies into the coexistence of genetically modified and conventional maize. COPA-COGECA colloquy on the co-existence and thresholds of adventitious presence on GMOs in conventional seeds, 2004. Available http://www.copa-cogeca.be/pdf/9.pdf. No date.

21. Weber W.E., Bringezu T., Broer I., Eder J., Holz F. Coexistence between GM and non-GM maize crops - tested in 2004 at the field scale level (Erprobungsanbau 2004). Journal of Agronomy and Crop Science, 2007, 193: 79-92 (doi:10.1111/j.1439-037X.2006.00245.x).

22. Palaudelmas M., Mele E., Monfort A., Serra J., Salvia J., Messeguer J. Assessment of the influence of field size on maize gene flow using SSR analysis. Transgenic Research, 2012, 21(3): 471483 (doi: 10.1007/s11248-011-9549-z).

23. Ingram $\mathbf{J}$. The separation distances required to ensure cross-pollination is below specified limits in non-seed crops of sugar beet, maize and oilseed rape. Plant Varieties and Seeds, 2000, 13(3): 181-199.

24. Novotny E., Perdang J. Report on a model for pollen transport by wind. In: Report for the Chardon LL hearing. London, 2002.

25. Westgate M., Lizaso J., Batchelor W. Quantitative relationship between pollen-shed density and grain yield in maize. Crop Science, 2003, 43: 934-942 (doi: 10.2135/cropsci2003.9340).

26. Bock A.-K., Lheureux K., Libeau-Dulos M., Nilsagard H., Rodriguez-Cerezo E. Scenarios for co-existence of genetically modified, conventional and organic crops in European agriculture. IPTS-JRC, Seville, Spain, 2002.

27. Brookes G., Barfoot P., Melé E., Messeguer J., Bénétrix F., Bloc D., Foueillassar X., Fabié A., Poeydomenge C. Genetically modified maize: pollen movement and crop coexistence. PG Economics Ltd., Dorchester, UK, 2004.

28. Du M., Kawashima S., Matsuo K., Yonemura S., Inoue S. Simulation of the effect of a cornfield on wind and pollen deposition. In: International Congress on Modelling and Simulation. F. Ghassemi, P. Whetton, R. Little, M. Littleboy (eds.). Australian National University, 2001: 899-903.

29. Liu Y., Chen F., Guan X., Li J. High crop barrier reduces gene flow from transgenic to conventional maize in large fields. European Journal of Agronomy, 2015, 71: 135-140 (doi: 10.1016/j.eja.2015.09.005).

30. Le Bail M., Lecroart B., Gauffreteau A., Angevin F., Messean A. Effect of the structural variables of landscapes on the risks of spatial dissemination between GM and non-GM maize. European Journal of Agronomy, 2010, 33: 12-23 (doi: 10.1016/j.eja.2010.02.002).

31. Henry C., Morgan D., Weekes R., Daniels R., Boffey C. Farm scale evaluations of GM crops: monitoring gene flow from GM crops to non-GM equivalent crops in the vicinity: Part I: Forage maize. DEFRA report EPG, 2003.

32. Weekes R., Allnutt T., Boffey C., Morgan S., Bilton M., Daniels R., Henry C. A study of cropto-crop gene flow using farm scale sites of fodder maize (Zea mays L.) in the UK. Transgenic Research, 2007, 16(2): 203-211 (doi: 10.1007/s11248-006-9036-0).

33. Devos Y., Demont M., Sanvido O. Coexistence in the EU - return of the moratorium on GM crops? Nature Biotechnology, 2008, 26(11): 1223-1225 (doi: 10.1038/nbt1108-1223).

34. Gustafson D.I., Brants I.O., Horak M.J., Remund K.M., Rosenbaum E.W., Soteres J.K. Empirical modeling of genetically-modified maize grain production practices to achieve European Union labeling thresholds. Crop Science, 2006, 46: 2133-2140 (doi: 10.2135/cropsci2006.01.0060).

35. Chamecki M., Gleicher S.C., Dufault N.S., Isard S.A. Diurnal variation in settling velocity of pollen released from maize and consequences for atmospheric dispersion and cross-pollination. $\mathrm{Ag}$ ricultural and Forest Meteorology, 2011, 151: 1055-1065 (doi: 10.1016/j.agrformet.2011.03.009).

36. Makowski D., Bancal R., Bensadoun A., Monod H., Messéan A. Sampling strategies for evaluating the rate of adventitious transgene presence in non-genetically modified crop fields. Risk Analysis, 2017, 37(9): 1693-1705 (doi: 10.1111/risa.12745).

37. Bohn T., Primicerio R., Traavik T. The German ban on GM maize MON810: scientifically justified or unjustified? Environmental Sciences Europe, 2012, 24(22): 1-7 (doi: 10.1186/21904715-24-22).

38. Della Porta G., Ederle D., Bucchini L., Prandi M., Verderio A., Pozzi C. Maize pollen mediated gene flow in the Po valley (Italy): Source-recipient distance and effect of flowering time. European Journal of Agronomy, 2008, 28: 255-265 (doi: 10.1016/j.eja.2007.07.009).

39. Popescu S., Leprince F., Ioja-Boldura O., Marutescu A., Sabau I., Marcela Badea E. Quantification of pollen mediated gene flow in maize. Romanian Biotechnological Letters, 2010, 15: 5351-5360.

40. Van de Wiel C.C.M., Groeneveld R.M.W., Dolstra O., Kok E.J., Scholtens I.M.J., Thissen J., Smulders M.J.M., Lotz L.A.P. Pollen-mediated gene flow in maize tested for coexistence of GM and non-GM crops in the Netherlands: Effect of isolation distances between fields. NjasWageningen Journal of Life Sciences, 2009, 56: 405-423 (doi: 10.1016/S1573-5214(09)80007-9).

41. Jaffe G. Regulating transgenic crops: a comparative analysis of different regulatory processes. 
Transgenic Research, 2004, 13: 5-19 (doi: 10.1023/B:TRAG.0000017198.80801.fb).

42. Nicolia A., Manzo A., Veronesi F., Rosellini D. An overview of the last 10 years of genetically engineered crop safety research. Critical Review Biotechnology, 2014, 34(1): 77-88 (doi: 10.3109/07388551.2013.823595).

43. Sirsi E. Coexistence: a new perspective, a new field. Agriculture and Agricultural Science Procedia, 2016, 8: 449-454 (doi: 10.1016/j.aaspro.2016.02.042).

44. Ujj O. European and American views on genetically modified foods. The New Atlantis, 2016, 49: 77-92.

45. EC (European Commission). 2015b. Fact sheet: Questions and answers on EU's policies on GMOs. Available http://europa.eu/rapid/press-release_MEMO-15-4778_en.htm. Accessed 30.11.2015.

46. Restrictions on Genetically Modified Organisms. Washington: Law Library of Congress, Global Legal Research Center, 2014. Available https://www.loc.gov/law/help/restrictions-ongmos/index.php. No date.

47. Deppermann A., Balkovic J., Bundle S.-C., Di Fulvio F., Havlík P., Leclure D., Lesiv M., Prishchepov A., Schepaschenko D. Increasing crop production in Russia and Ukraine - regional and global impacts from intensification and recultivation. Environmental Research Letters, 2018, 13: 025008 (doi: 10.1088/1748-9326/aaa4a4).

48. Clive J. Global status of commercialized biotech/gm crops: 2014. ISAAA Brief No. 49. ISAAA, Ithaca, NY, 2014.

49. Brookes G., Barfoot P. Farm income and production impacts of using GM crop technology 1996-2016. GM Crops \& Food, 2018, 9: 59-89 (doi: 10.1080/21645698.2018.1464866).

50. Zhuchenko A.A. Role of genetic engeneering in adaptive system of plant breeding (myths and reality). Sel'skokhozyaistvennaya Biologiya [Agricultural Biology], 2003, 1: 3-33.

51. Zhivotovskii L.A. V sbornike: GMO - skrytaya ugroza Rossii /Pod redaktsiei I.V. Starikova [In: GMO - the hidden threat to Russia. I.V. Starikov (ed.)]. Moscow, 2004: 94-104 (in Russ.).

52. Muir W.M., Howard R.D. Possible ecological risks of transgenic organism release when transgenes affect mating success: Sexual selection and the Trojan gene hypothesis. Proc. Natl. Acad. Sci. USA, 1999, 96 (24): 13853-13856 (doi: 10.1073/pnas.96.24.13853).

53. Piperno D.R., Flannery K.V. The earliest archaeological maize (Zea mays L.) from highland Mexico: new accelerator mass spectrometry dates and their implications. Proc. Natl. Acad. Sci. USA, 2001, 98: 2101-2103 (doi: 10.1073/pnas.98.4.2101).

54. Cárdenas F. Latin American maize germplasm regeneration and conservation. In: Proc. Workshop CIMMYT, Mexico, June 4-6, 1996. S. Taba (ed.). CIMMYT, Mexico, 1997: 74.

55. Serratos-Hernandez J.-A., Islas-Gutierrez F., Buendia-Rjdrigueez E., Berthaud J. Gene flow scenarios with transgenic maize in Mexico. Environmental Biosafety Research, 2004. 3: 149-157 (doi: 10.1051/ebr:2004013).

56. Quist D., Chapela I.H. Transgenic DNA introgressed into traditional maize landraces in Oaxaca, Mexico. Nature, 2001, 41: 541-543 (doi: 10.1038/35107068).

57. Ortiz-Garcia S., Ezcurra E., Schoel B., Acevedo F., Soberon J., Snow A.A. Absence of detectable transgenes in local landraces of maize in Oaxaca, Mexico (2003-2004). Proc. Natl. Acad. Sci. USA, 2005, 102(35): 12338-12343 (doi: 10.1073/ pnas.0503356102).

58. Bellon M.R., Berthaud J. Transgenic maize and the evolution of landrace diversity in Mexico. The importance of farmers' behavior. Plant Physiology, 2004, 134: 883-888 (doi: 10.1104/pp.103.038331).

59. McHughen A. A critical assessment of regulatory triggers for products of biotechnology: Product vs. process. GM Crops \& Food, 2016, 7: 125-158 (doi: 10.1080/21645698.2016.1228516).

60. Ramessar K., Capell T., Twyman R.M., Quemada H., Christou P. Trace and traceability - a call for regulatory harmony. Natural Biotechnology, 2008, 26: 975-978 (doi: 10.1038/nbt0908-975).

61. Tetsuya I., Motoko A. A future scenario of the global regulatory landscape regarding genomeedited crops. GM Crops \& Food, 2017, 8(1): 44-56 (doi: 10.1080/21645698.2016.1261787).

62. Baram M. Governance of GM crop and food safety in the United States. In: Governing risk in GM agriculture. M. Baram, M. Bourrier (eds.). Cambridge University Press. 2011: 15-55.

63. Nabradi A., Popp J. Economics of GM crop cultivation. Applied Studies in Agribusiness and Commerce, 2011, 05: 7-19 (doi: 10.19041/Apstract/2011/3-4/1)

64. Xu Z., Hennessy D.A., Sardana K., Moschini G.C. The realized yield eject of genetically engineered crops: U.S. maize and soybean. Crop Science, 2013, 53: 735-745 (doi: 10.2135/cropsci2012.06.0399).

65. Eastham K., Sweet J. Genetically modified organisms (GMOs): the significance of gene flow through pollen transfer. In: European Environment Agency. Environmental issue report. D. Gee (ed.). Copenhagen, 2002, 28: 38-42.

66. Lee M.S., Anderson E.K., Stojšin D., McPherson M.A., Baltazar B., Horak M.J., de la Fuente J.M., Wu K., Crowley J.H., Rayburn A.L., Lee D.K. Assessment of the potential for gene flow from transgenic maize (Zea mays L.) to eastern gamagrass (Tripsacum dactyloides L.). Transgenic Research, 2017, 26(4): 501-514 (doi: 10.1007/s11248-017-0020-7).

67. Instituto Colombiano Agropecuario. Por medio de la cual se implementa el plan de manejo, bioseguridad y seguimiento para siembras controladas de maíz genéticamente modificado. Resoluciyn No. 
2894. Bogota, 2010.

68. Chaparro-Giraldo A., Blanco M.J.T., López-Pazos S.A. Evidence of gene flow between transgenic and non-transgenic maize in Colombia. Agronomнa Colombiana, 2015, 33(3): 297-304 (doi: 10.15446/agron.colomb.v33n3.51501).

69. Vicién C., Trigo E. The Argentinian GMO biosafety system: an evolving perspective. In: Genetically modified organisms in developing countries risk analysis and governance. A. Adendle, E. Jane Morris, J. Denis (eds.). Cambridge University Press, Cambridge, UK, 2017: 247-257 (doi: 10.1017/9781316585269.022).

70. Burachik M. Experience from use of GMOs in Argentinian agriculture, economy and environment. New Biotechnology, 2010, 27(5): 588-592 (doi: 10.1016/j.nbt.2010.05.011).

71. Coelho M.V.S. Coexistence in Brazil. In: The coexistence of genetically modified, organic and conventional foods. N. Kalaitzandonakes, P. Phillips, J. Wesseler, S. Smyth (eds.). Natural Resource Management and Policy, Springer, NY, USA, 2016, 49: 87-94 (doi: 10.1007/978-14939-3727-1_8).

72. Viljoen C., Chetty L. A case study of GM maize gene flow in South Africa. Environmental Sciences Europe, 2011, 23: 1-8 (doi: 10.1186/2190-4715-23-8).

73. Wang C.Y., Kuo B.J., Hsu Y.H., Yiu T.J., Lin W.S. Using the two-step model based on the field border consideration to evaluate pollen-mediated gene flow (PMGF) model and the isolation distance of GM maize in Potzu city of Chiayi county. Crop, Environment \& Bioinformatics, 2013, 10: 172-189 (doi: 10.1371/journal.pone.0131549).

74. Smyth S.J. Genetically modified crops, regulatory delays, and international trade. Food Energy Security, 2017, 6: 78-86 (doi: 10.1002/fes3.100).

75. Bückmann H., Capellades G., Hamouzová K., Holec J., Soukup J., Messeguer J., Melé E., Nadal A., Guillen X.P., Pla M., Serra J., Thiele K., Schiemann J. Cytoplasmic male sterility as a biological confinement tool for maize coexistence: Optimization of pollinator spatial arrangement. Plant, Soil and Environment, 2017, 63: 145-151 (doi: 10.17221/761/2016-PSE).

76. Bruns H.A. Southern corn leaf blight: a story worth retelling. Agronomy Journal. 2017, 109: 1218-1224 (doi: 10.2134/agronj2017.01.0006).

77. Schnable P.S., Wise R.P. The molecular basis of cytoplasmic male sterility and fertility restoration. Trends in Plant Science, 1998, 3: 175-180 (doi: 10.1016/S1360-1385(98)01235-7).

78. Su A., Song W., Xing J., Zhao Y., Zhang R., Li C., Duan M., Luo M., Shi Z., Zhao J. identification of genes potentially associated with the fertility instability of S-type cytoplasmic male sterility in maize via bulked segregant RNA-seq. PLoS ONE, 2016, 11(9): e0163489 (doi: 10.1371/journal.pone.0163489).

79. Liu Y., Wei G., Xia Y., Liu X., Tang J., Lu Y., Lan H., Zhang S., Li C., Cao M. Comparative transcriptome analysis reveals that tricarboxylic acid cycle-related genes are associated with maize CMS-C fertility restoration. BMC Plant Biology, 2018, 18(1): 190 (doi: 10.1186/s12870018-1409-z).

80. Herman R.A., Zhuang M., Storer N.P., Cnudde F., Delaney B. Risk-only assessment of genetically engineered crops is risky. Trends in Plant Science, 2019, 24(1): 58-68 (doi: 10.1016/j.tplants.2018.10.001).

81. Bückmann H., Hüsken A., Schiemann J. Applicability of cytoplasmic male sterility (CMS) as a reliable biological confinement method for the cultivation of genetically modified maize in Germany. Journal of Agricultural Science and Technology, 2013, A3: 385-403.

82. Bückmann H., Thiele K., Schiemann J., Husken A. Influence of air temperature on the stability of cytoplasmic male sterility (CMS) in maize (Zea mays L.). AgBioForum, 2014, 2: 205-212.

83. Bückmann H., Thiele K., Schiemann J. CMS maize: a tool to reduce the distance between GM and non-GM maize. EuroChoices, 2016, 15(1): 31-35 (doi: 10.1111/1746-692X.12116).

84. Wan X., Wu S., Li Z., Dong Z., An X., Ma B., Tian Y., Li J. Maize genic male-sterility genes and their applications in hybrid breeding: progress and perspectives. Molecular Plant, 2019, 12(3): 321-342 (doi: 10.1016/j.molp.2019.01.014).

85. Wu Y., Fox T.W., Trimnell M.R., Wang L., Xu R.J., Cigan A.M., Huffman G.A., Garnaat C.W., Hershey H., Albertsen M.C. Development of a novel recessive genetic male sterility system for hybrid seed production in maize and other cross pollinating crops. Plant Biotechnology Journal, 2016, 14: 1046-1054 (doi: 10.1111/pbi.12477).

86. Zhang D., Wu S., An X., Xie K., Dong Z., Zhou Y., Xu L., Fang W., Liu S., Liu S., Zhu T., Li J., Rao L., Zhao J., Wan X. Construction of a multicontrol sterility system for a maize malesterile line and hybrid seed production based on the ZmMs7 gene encoding a PHD-finger transcription factor. Plant Biotechnology Journal, 2018, 16: 459-471 (doi: 10.1111/pbi.12786).

87. Feng P.C., Qi Y., Chiu T., Stoecker M.A., Schuster C.L., Johnson S.C., Fonseca A.E., Huang J. Improving hybrid seed production in corn with glyphosate-mediated male sterility. Pest Management Science, 2014, 70: 212-218 (doi: 10.1002/ps.3526).

88. Xie K., Wu S., Li Z., Zhou Y., Zhang D., Dong Z., An X., Zhu T., Zhang S., Liu S., Li J., Wan X. Map-based cloning and characterization of Zea mays male sterility33 (ZmMs33) gene, encoding a glycerol-3-phosphate acyltransferase. Theoretical and Applied Genetics, 2018, 131: 
1363 (doi: 10.1007/s00122-018-3083-9).

89. Chen R., Xu Q., Liu Y., Zhang J., Ren D., Wang G., Liu Y. Generation of transgene-free maize male sterile lines using the CRISPR/Cas9 system. Frontiers in Plant Science, 2018, 9: 1180 (doi: 10.3389/fpls.2018.01180).

90. Svitashev S., Schwartz C., Lenderts B., Young J.K., Mark C.A. Genome editing in maize directed by CRISPR-Cas9 ribonucleoprotein complexes. Nature Communications, 2016, 7: 13274 (doi: 10.1038/ncomms13274).

91. Sanvido O., Widmer F., Winzeler M., Streit B., Szerencsits E., Bigler F. Definition and feasibility of isolation distances for transgenic maize cultivation. Transgenic Research, 2008, 17: 317 335 (doi: 10.1007/s11248-007-9103-1).

92. Devos Y., Demont M., Dillen K., Reheul D., Kaiser M., Sanvido O. Coexistence of genetically modified (GM) and non-GM crops in the European Union (review). Agronomy for Sustainable Development, 2009, 29: 11-30 (doi: 10.1051/agro:2008051).

93. Riesgo L., Areal F.J., Sanvido O., Rodriguez-Cerezo E. Distances needed to limit crossfertilization between GM and conventional maize in Europe. Nature Biotechnology, 2010, 28: 780-782 (doi: 10.1038/nbt0810-780).

94. Langhof M., Hommel B., Hüsken A., Njontie C., Schiemann J., Wehling P., Wilhelm R., Rühl G. Coexistence in maize: isolation distance in dependence on conventional maize field depth and separate edge harvest. Crop Science, 2010, 50: 1496-1508 (doi: 10.2135/cropsci2009.11.0641).

95. Marceau A., Saint-Jean S., Loubet B., Foueillassar X., Huber L. Biophysical characteristics of maize pollen: Variability during emission and consequences on cross-pollination risks. Field Crops Research, 2012, 127: 51-63 (doi: 10.1016/j.fcr.2011.11.006).

96. Venus T.J., Dillen K., Punt M.J., Wesseler J.H. The costs of coexistence measures for genetically modified maize in Germany. Journal of Agricultural Economics, 2017, 68: 407-426 (doi:10.1111/1477-9552.12178). 